\title{
The Ratification and Status of the International Treaties in the Legal System of the Islamic Republic of Iran
}

\author{
Seyed Ahmad Tabatabaei ${ }^{1} \&$ Siamak Karamzadeh $^{2}$ \\ ${ }^{1}$ Assistant Professor, Faculty of Law, College of Farabi, University of Tehran, Qom, Iran \\ ${ }^{2}$ Humanities Faculty, Shahed University, Tehran, Iran \\ Correspondence: Seyed Ahmad Tabatabaei, Faculty of Law, College of Farabi, University of Tehran, Qom, Iran. \\ E-mail: sataba@ut.ac.ir
}

Received: August 7, 2017

doi:10.5539/jpl.v10n5p85
Accepted: September 21, 2017

Online Published: November 29, 2017

URL: https://doi.org/10.5539/jpl.v10n5p85

\begin{abstract}
After the Islamic revolution in Iran in 1979, fundamental changes occurred in Iran's political and legal system. Pursuant the referendum on creating the Islamic Republic in March 1979, the new constitution came into force in the same year and many of the ordinary laws of the country were also reformed. The purpose of this study is to consider the method of ratification of international treaties and the status of these instruments in the legal system of Iran. Firstly, the stages of the ratification of treaties in Iran's legal system have been explained. Secondly, the position of treaties among the other laws is discussed. This study concludes that, the international treaties, like ordinary laws, primarily should be passed by the Islamic Consultative Assembly; and after the approval of the Guardian Council, they should be signed by the President. Under the Constitution of Iran all international treaties should all be ratified by the Islamic Consultative Assembly (parliament) and the Guardian Council; however, based on the interpretations of the Guardian Council and the executive procedures, some treaties have been excluded from the ratification of the Islamic Consultative Assembly. International treaties may enjoy a higher position than that of the ordinary law through an objective interpretation, although they have been recognized as ordinary laws by the Article 9 of the Civil Code of Iran.
\end{abstract}

Keywords: Iran, international treaties, Constitution of the Islamic Republic of Iran, public law, ratification, Islamic Consultative Assembly, guardian council

\section{Introduction}

In the second half of the 1970s, the emergence of social protests against the Pahlavi regime in Iran advanced from intellectual spheres to public zones and it turned into a vast revolution throughout the country. Eventually, in February $12^{\text {th }}, 1979$ after the fall of the ruling regime, the Islamic Republic system was founded. The new constitution was written and many domestic laws were reformed (Note 1). In the new legal system, based on the Constitution, the relative separation of the powers was approved; and apart from the three main powers, the Leading Authority, invested with considerable power, was established. Since 1979, the Constitution of Iran has been reformed just once in 1989 through the referendum. This reform is not concerned with the issue of international treaties.

It is necessary to provide some explanations about the approach and the sensitivities of the Iran's Constitution. The unfavorable background in the political history of Iran, because of the internal dictatorship and foreign hegemony, has been repeatedly referred to in the Constitution. For instance, in the introduction of the Constitution, after a reference to the Islamic Revolution, one reads: "The Muslim people of Iran, after living through an anti-despotic movement for constitutional government, and anti-colonialist movement for the nationalization of petroleum, gained precious experience in that they realized that the basic and specific reason for the failure of those movements was that they were not religious ones...". The content of the Constitution, concerning the international relations and conclusion of international agreements, has been influenced by this history; consequently, there has been an emphasis on the supervision of the international affairs and the discontinuity of foreign hegemony. Furthermore, as it will be observed, based on the Islamic nature of the Revolution of Iran, the Constitution has emphasized that the Islamic rules should be followed for all decisions and law-making processes, including ratification of the international treaties. 
The international treaties can be studied from two viewpoints, namely, national constitutional law and international law. This paper scrutinizes this issue from the viewpoint of the constitutional law of Iran. Concerning the method of ratification, interpretation, implementation and publication of the treaties in the domestic law of Iran, the basic point to be considered is that based on Article 9 of the Civil Code of the Islamic Republic of Iran (1928), international treaties are considered as ordinary laws. In other words, as it will be explained, many substantive and procedural issues that are related to the passage, interpretation and publication of the ordinary laws also apply to the treaties. The significance of this approach is that it will be useful in cases in which there are ambiguities or lack of explanation in the Constitution concerning the ratification and status of treaties.

The innovation of this research is that, it resorts to practical approaches and legal interpretive opinions concerning the international treaties, which developed after the formation of the Constitution. It should be taken into consideration that according to Article 98 of the Constitution, "The authority of the interpretation of the Constitution is vested with the Guardian Council, which is to be done with the consent of three-fourths of its members". The Guardian Council has dealt with this issue in two ways:

1) Official interpretation of the articles of the Constitution

2) Indirect interpretation of the articles of the Constitution, through suggesting opinions at the stage of approval of the laws and treaties

In this study, for a better understanding of the Constitution, besides referring to the opinions and interpretations of the Guardian Council, the relevant ordinary laws and regulations have also been referred to. The main purpose of this study is to provide a general perspective of the status of the treaties in the constitutional law of Iran. Certainly, each of the discussed issues in this research can also be examined in individual papers with a prominent focus on details.

\section{The Procedure of International Treaties' Ratification}

In this section, initially the major concepts used in the research, i.e. 'international treaties', ratification' and 'accession', are defined. Next, the steps of ratification of international treaties in the legal system of Iran will be discussed. In brief, the treaties, like ordinary laws, should first be approved by the Islamic Consultative Assembly (hereinafter: the Parliament), next they should be approved by the Guardian Council and finally, they need to be signed by the President.

\subsection{Concepts}

\subsubsection{Meaning of International Treaties}

The Vienna Convention on the Law of Treaties (1969) provides: "Treaty means an international agreement concluded between States in written form and governed by international law, whether embodied in a single instrument or in two or more related instruments and whatever its particular designation is."(Paragraph 1(a), Article 2). In international law, various titles are used to refer to international agreements, including treaty, convention, contract, protocol, covenant, charter, statute, declaration, and pact. Based on this definition, the agreements under the international law, regardless of their titles, are considered international treaties. Needless to say, according to this description, only the agreements between states themselves were considered international treaties and the definition did not include the agreements between states and international organizations. This deficiency was removed by the Vienna Convention on the Law of Treaties between States and International Organizations or between International Organizations (1986) in which the above-mentioned agreements are considered as international treaties.

Under Iranian law, the Regulation of the Manner of Making International Agreements (Article 1) provides the following definition:

The legal agreement is an agreement resulted from international relations through which a governmental organization undertakes an obligation before states, foreign governmental institutes and corporations, or international assemblies, councils and organizations; such agreements enjoy legal effect and they have to be implemented.

\subsubsection{Meaning of Ratification}

According to the international law, the most of multilateral treaties do not come into force just through signature; rather, they should also be ratified by the authorities of the states. Ratification may be described as:

Ratification defines the international act whereby a state indicates its consent to be bound to a treaty if the parties intended to show their consent by such an act. In the case of bilateral treaties, ratification is 
usually accomplished by exchanging the requisite instruments, while in the case of multilateral treaties the usual procedure is for the depositary to collect the ratifications of all states, keeping all parties informed of the situation. The institution of ratification grants states the necessary time-frame to seek the required approval for the treaty on the domestic level and to enact the necessary legislation to give domestic effect to that treaty (UN Website, Treaty Collection link).

\subsubsection{Meaning of Accession}

If a state has not signed a treaty in due terms, but intends to join the treaty, it can do so through accession. Practically, the process of accession in the municipal law of states is the same procedure as that of ratification. In the Constitution of Iran, no distinction has been made between ratification and accession. In fact, the stages of accession will be similar to those of ratification. In the Constitution of Iran, ratification and accession have not been explicitly defined; however, the Regulation of the Manner of Making International Agreements, in such cases implicitly accepts the definitions provided in international instruments.

The authority for ratification is governed by the constitutional law of each country. In the constitutional law of Iran, treaties should be passed by the Parliament, subsequently, they should be approved by the Guardian Council and signed by the President. If the Guardian Council disapproves a passed case by the Parliament, and the Parliament insists on its passage, it would be dispatched to another institute called 'the Expediency Council'. In the next section, the above-mentioned process will be considered.

\subsection{Passage of Treaties in the Parliament}

Article 77 of Iran's Constitution provides that treaties, like ordinary laws, should be passed by the Parliament: "International treaties, protocols, contracts, and agreements must be approved in the Islamic Consultative Assembly." Ordinary laws are presented to the Parliament in two ways, either by the government, or by the Parliament itself. Treaties are usually presented by the government to the Parliament, and the Parliament rarely suggests membership in international treaties or organizations. The sessions of the Parliament are legally valid through the presence of two-third of all its members, and the passage of drafts and bills takes place in accordance with the Internal Regulation of the Parliament (Constitution of the Islamic Republic of Iran, Article 65, 1979). According to the Internal Regulation of the Parliament, decisions of the Parliament (including ordinary laws and treaties), should be passed by the absolute majority (half +1 ) of the present members, unless another procedure has been provided for the case (Internal Regulation of the Parliament, Article 118, 1990). If a treaty is signed by an executive authority, the Parliament is not obliged to ratify that treaty (Enayat, 1991, p. 68) (Note 2).

Although there is no reference in the Constitution about the accession to treaties, the Guardian Council, in its interpretive opinion, has considered the bills of accession of Iran to international communities and organizations, as ratification of international agreements; therefore, they should be passed in the Parliament (Imani \& Qetmiri, 2009 , p. 549, Interpretive Opinion, January $\left.12^{\text {th }}, 1988\right)$.

\subsubsection{Executive Agreements}

In many countries, to facilitate international relations and the settlement of insignificant treaties, simpler ways are anticipated; such treaties come into force just through the signature of authorities of the executive power and there is no need for them to be ratified by the Parliament. In the Constitution of Iran, no distinction has been considered between the executive and official agreements. Article 77 declares that all treaties require ratification by the Parliament. However, in the Regulation of the Manner of Making International Agreements (Articles 16 and 17) (Note 3) and the opinions of the Guardian Council, simple and executive agreements have been recognized (Enayat, 1991, pp. 77-87\& 96-97). For example, in the opinion of the Guardian Council, there is no need for ratification of the agreements for making deals between the ministry offices or governmental corporations of Iran and foreign governmental corporations (Guardian Council's Research Center, 2010, p. 112, Interpretive Opinion No. 2009, November $7^{\text {th }}, 1984$ ).

The Guardian Council also believes that minor agreements which are beyond the coverage of the major agreements ought to be ratified by the Parliament (Mousa Zadeh, et al, 2011, p. 441, Opinion No. 9993, November $\left.29^{\text {th }}, 1983\right)$. Therefore, it is implied from the opinion of the Guardian Council that minor contracts included by the major agreements do not need to be ratified (Note 4).

In practice, based on the objective interpretations of the opinions of the Guardian Council, more agreements are dealt with as executive agreements. There is a different legal doctrine concerning the scope of the executive treaties in Iran. Some lawyers, based on the political and social requirements, desire to extend the scope of interpretations made by the Guardian Council (Falsafi, 2000, pp. 171-172). Still, some confine themselves to the explicit utterance of Article 77, and negate the existence of simple agreements under Iranian law in the law of 
Iran, or at least deny their extensiveness (Ziaei Bigdel, 2009, p. 114). A closer study of the issue of simple agreements under Iranian law requires an independent research, which is beyond the scope of this paper (Haddadi, 2002, pp. 113-149).

The other point to be discussed is the legal effects of the memorandums of understanding. Normally, these instruments have an etiquette nature and they are considered as an introduction to making treaties. Therefore, they do not generally bring about any legal responsibility for the parties. Based on the opinion of the Guardian Council, "A memorandum of understanding which brings responsibility is like a treaty and the relevant mentioned regulations in the Constitution should be applied to them" (Mousa Zadeh, et al, 2011, p. 441, Opinion No. 9993, November $29^{\text {th }}, 1983$ ). In accordance with the above opinion, agreements whose content and relevant evidence bring responsibility, should be approved by Parliament even if they are named as memorandums of understanding.

\subsubsection{Amendment to the Treaties}

The Constitution of Iran is silent on the manner of changing and amending the treaties. According to the opinions of the Guardian Council, in addition to the necessity of the approval of treaties by the Parliament, possible modifications to the treaties should also be passed by the Parliament. A number of bills, on making bilateral agreements or accession to multilateral conventions, were passed in the Parliament and were sent to the Guardian Council for approval. More than ten cases of such conventions in which their revision had been authorized, without the Parliament's passage were considered by the Guardian Council as invalid and incompatible with Article 77 of the Constitution (Mousa Zadeh, et al, 2011, pp. 435-441, Opinion No. 86/30/22304).

\subsubsection{Termination of the Treaties}

The Constitution is also silent as to the mechanism of termination of treaties and whether the termination should be passed by the Parliament or not. The Guardian Council in its opinion has announced that the termination of contracts with foreign corporations and institutes does not need to be passed by the Parliament (Guardian Council's Research Center, 2010, p. 28). Of course, it still remains unsolved whether or not the termination of multilateral and important treaties of Iran with other states is exempt from being voted by the Parliament, as well. It seems that the above-mentioned opinion of the Guardian Council is concerned with insignificant treaties, and therefore, the termination of multilateral treaties needs to be passed by the Parliament.

\subsubsection{Referendum}

The Constitution determines that the Parliament can make decisions through referendum, concerning important issues:

In extremely important economic, political, social, and cultural matters, the function of the legislature may be exercised through direct recourse to popular vote through a referendum. Any request for such direct recourse to public opinion must be approved by two-thirds of the members of the Islamic Consultative Assembly (Constitution of the Islamic Republic of Iran, Article 59, 1979).

Theoretically, the above provision of the Constitution may include some important international treaties as well. In this case, membership in a vital treaty may depend on the approval of the public opinion. There has been no such referendum in Iran, but there are such cases in other countries. For instance, in Switzerland, decision making about membership in the United Nations was done in March 2002 through the referendum; and it was supported by $55 \%$ of the voters.

According to the third paragraph of Article 110, concerning referendum for amending the Constitution of Iran, the order of referendum is issued by the Supreme Leader; however, concerning the referendum for important issues, subject to Article 59, the Referendum Act does not necessitate the order of the Supreme Leader. In the next section, the necessity of the approval of referendum and its result by the Guardian Council will be studied.

\subsection{Approval of Treaties by the Guardian Council}

The Guardian Council is one of the constitutional organs and, in fact, it is an inseparable part of the legislative power. Article 91 of the Constitution determines that:

With a view to safeguarding the Islamic ordinances and the Constitution, in order to examine the compatibility of the legislation passed by the Islamic Consultative Assembly with Islamic laws, a council to be known as the Guardian Council is to be constituted with the following composition:

1) Six religious men [fuqaha], conscious of the present needs and the issues of the day, to be selected by the Leader; 
2) Six jurists, specialized in different areas of law, are elected by the Islamic Consultative Assembly from among the Muslim jurists, nominated by the Head of the Judicial Power.

All passages of the Parliament, including decisions concerning membership in international treaties, should be approved by the Council. The Article 4 of the Constitution determines that:

All civil, penal, financial, economic, administrative, cultural, military, political, and other laws and regulations must be based on Islamic criteria. This article applies absolutely and generally to all articles of the Constitution as well as to all other laws and regulations, and the 'fuqaha' [religious men] of the Guardian Council are judges in this matter.

The Guardian Council not only validates the approvals of the Parliament, but it also verifies the existence and validity of the very Parliament, itself: "The Islamic Consultative Assembly does not hold any legal status if there is no Guardian Council in existence, except for the purpose of approving the credentials of its members and the election of the six jurists on the Guardian Council" (Constitution of the Islamic Republic of Iran, Article 93, 1979). In the Constitution, despite the explicit emphasis on the point that treaties should be passed by the Parliament, the approval of the treaties by the Guardian Council, has been indirectly referred to:

All legislation passed by the Islamic Consultative Assembly must be sent to the Guardian Council. The Guardian Council must review it within a maximum of ten days from its receipt with a view to ensuring its compatibility with the criteria of Islam and the Constitution. If it finds the legislation incompatible, it will return it to the Assembly for review. Otherwise the legislation will be deemed enforceable (Constitution of the Islamic Republic of Iran, Article 94, 1979).

Considering Articles 4, 77, and 94, and the absoluteness of Articles 4 and 94, it becomes evident that after the passage of treaties by the Parliament, they should also be approved by the Guardian Council. Concerning the manner of voting in the Guardian Council, Article 96 determines that:

The determination of compatibility of the legislation passed by the Islamic Consultative Assembly with the Islamic law rests with the majority vote of the 'fuqaha' in the Guardian Council; and the determination of its compatibility with the Constitution rests with the majority of all the members of the Guardian Council.

Based on Article 94 of the Constitution, up to now, tens of bills passed by the Parliament regarding various treaties, have been rejected by the Guardian Council. Most of these bilateral treaties have been associated with the extradition of criminals between state parties, and legal assistance between Iran and other states. As it will be explained in the next section, the Parliament has succeeded to pass most of these treaties through appealing to the Expediency Council (Expediency Council Website: http://maslahat.ir/DocLib2/Approved\%20Policies/Noncom patabilities.aspx). Among the remarkable cases of the rejection of official multilateral treaties by the Guardian Council, one can refer to the legislation passed by the Parliament concerning the accession to the Convention on the Elimination of All Forms of Discrimination against Women, 1979. The Guardian Council considered this convention against the Islamic rules and the Constitution. (Mousa Zadeh, et al, 2011, p.4) (Note 5).

The important point to be mentioned here is that the treaties ratified before the Islamic Revolution and by the former regime are excluded from the approval of the Guardian Council. From the legal point of view, Iran is obliged to implement these treaties. This issue has resulted in serious challenges regarding some of the former international treaties related to human rights. As a remarkable instance, one can refer to the International Covenant on Civil and Political Rights, 1966, which had been ratified by the former regime without any reservation in 1976. In the Islamic regime, some of its provisions are incompatible with the municipal law or Islamic rules and therefore, they are impossible to be enforced.

As mentioned earlier, the Parliament can decide on joining a treaty by a referendum. The Constitution is silent as to the necessity of the approval of the request for a referendum and the approval of its result, by the Guardian Council. Based on the nature of the Constitution and its sensitivity toward the Islamic jurisprudential rules, most lawyers believe that requesting a referendum should be approved by the Guardian Council (Mehrpour, 2009, pp. 279-282).

Moreover, the interpretive opinion of the Guardian Council, based on Article 94, announces that the request for referring to the public votes is an instance which must be governed by Article 59 and it should be sent to the Guardian Council. (Mousa Zadeh, et al, 2011, p. 255, Interpretive Opinion 81/30/4104, March 16th, 2003). Concerning the result of the referendum, Article 27 of the Referendum Act proclaims that after the approval of the Guardian Council, the result of the referendum should be signed by the President. 


\subsection{Role of the Expediency Council}

During the first decade of the Islamic Republic, there were numerous cases of disagreement between the Parliament and the Guardian Council regarding the Parliament legislations. To eradicate this problem, in an amendment of the Constitution in 1989, the Expediency Council (also known as Exigency Council) was created, as a new constitutional organ, in support of the Parliament:

Upon the order of the Leader, the Nation's Exigency Council shall meet at any time the Guardian Council judges a proposed bill of the Islamic Consultative Assembly to be against the principles of Shariah [Islamic rules] or the Constitution, and the Assembly is unable to meet the expectations of the Guardian Council. Also, the Council shall meet for consideration on any issue forwarded to it by the Leader and shall carry out any other responsibility as mentioned in this Constitution... (Constitution of the Islamic Republic of Iran, Article 112, 1979) (Note 6).

Therefore, an issue is forwarded to the Expediency Council when a legislation passed by the Parliament is rejected by the Guardian Council, and the Parliament, for some expediency, insists on its approval (Note 7). From 1999 to 2009, 25 treaties were forwarded to the Expediency Council, out of which 21 were bilateral treaties, mostly related to the extradition of criminals and legal assistance between Iran and other states. The trend reveals that the Expediency Council has supported the Parliament, and most of the above mentioned treaties have been approved by the Expediency Council. (Website of the Expediency Council, Op. Cit.). Additionally, four multilateral treaties have been forwarded in this way to the Council and all have been approved by the Council. One of these treaties is the accession of Iran to WHO Framework Convention on Tobacco Control 2003, which was confirmed by the Expediency Council despite being rejected by the Guardian Council. (Website of the Expediency Council, Ibid.)

\subsection{Signature by the President}

The last stage of ratification of the international treaties is the President's signing, in accordance with Article 123 of the Constitution:

The President is obliged to sign legislation approved by the Parliament or the result of a referendum, after the related legal procedures have been completed and it has been communicated to him. After signing, he must forward it to the responsible authorities for implementation.

This article is unconditional and covers all passages of the Parliament. In other words, treaties are also implicitly included. Moreover, Article 125 of the Constitution explicitly considers the signing of the treaties as the President's duty, as follows:

The President or his legal representative has the authority to sign treaties, protocols, contracts, and agreements concluded by the Iranian government with other governments, as well as agreements pertaining to international organizations, after obtaining the approval of the Islamic Consultative Assembly.

Of course, the President's signing is formal; if he/she does not sign in due terms, the legislations of the Parliament, including treaties, will be published in the Official Gazette and will be legally effective. The Constitution is silent as to the deadline for signing or the measures to be taken regarding the cases, in which the President evades signing the passed bills. In order to remove the ambiguity, the Parliament passed the Act of Determining the Legal Deadline for Implementing Article 123 of the Constitution (1981), by which the legislation would progress automatically, if the President does not sign the legislations of the Parliament or the outcome of the referendum in five days from the announcement. (Mehrpour, 2009, pp. 214-215). Furthermore, the Amended Article 1 of the Civil Code (Note 8) clarifies that:

The legislations passed by the Islamic Consultative Assembly and the outcome of referendums, after the related legal procedures have been completed, will be forwarded to the President. The President should sign and forward them in five days to executers and should issue the order for their publication. The official newspaper is obliged to publish them in a term of 72 hours after they have been forwarded.

Note - In case the President avoids signing or forwarding them in due terms the Official Gazette is obliged to publish the passed legislation in a term of 72 hours.

Article 1 does not explicitly refer to treaties; however, it can be argued that 'Parliament's legislation' is an inclusive concept that includes treaties as well. Despite the above explicitness, there is also another opinion, which argues for the free will of the President concerning the signing of the forwarded treaties. (Imani \& Qetmiri, 2009, p. 
760).

\section{Publishing and Enforcing of the Treaties}

Article 102 of the UN Charter provides that every treaty and every international agreement shall be registered with the UN Secretariat and published by it. Furthermore, in Iran's legal system, international treaties are not enforced until they are published in internal newspapers, just like the ordinary laws.

\subsection{Publication in the Official Gazette}

According to Article 3 of the Civil Code, "Publication of laws should be through official newspapers". This means that, the legislations passed by the Parliament, including laws and international treaties, need to be published in an official newspaper and they are not valid without publication. As it was observed, under amended Article 1 of the Civil Code, the official newspaper is obliged to publish the laws or the passed legislations in 72 hours, after they are forwarded by the President. According to the Note of Article 1, if the President avoids signing or forwarding the laws, upon the order of the head of the Parliament, the official newspaper is still compelled to publish the Parliament's passed legislation in 72 hours; however, in some cases, instead of publishing the full text of a treaty, a Single Article, determining the passage of the treaty by the Parliament, is published. (Enayat, 1991, p. 239).

\subsection{Treaties Entering into Force}

Normally, the manner and the time in which international treaties enter into force are determined in the international treaties themselves. In bilateral treaties, this is generally realized through the exchange of ratification instruments; however, multilateral treaties generally enter into force after the deposit of a determined number of ratification instruments by states. Under Iranian law, there is no suggestion regarding the manner in which international treaties come into force. Article 2 of the Civil Code provides that: "laws are effective fifteen days after they are published all over the country, unless there is a specific procedure anticipated in the law itself, concerning the time of enforcement" (Note 9). Therefore, the provisions of treaties concerning the method of their enforcement have been implicitly accepted in the legal system of Iran.

\subsection{Implementation of Treaties before the Ratification}

Article 25 of the Vienna Convention (1969) endorses the provisional application of treaties, if this matter is mentioned in the treaties themselves. Although the Iran's Constitution does not explicitly state any regulations concerning the application of treaties before their ratification, the legal logic and implications of Articles 77 and 125 suggest that the execution of treaties before ratification is incompatible with the Constitution. Furthermore, the opinions of the Guardian Council also verify this view. The Guardian Council considered it incompatible with the Constitution, if Iran wishes to trade with Syria provisionally, before ratification of the related agreement. The same is true concerning the Air Transportation Agreement between Iran and the Kingdom of Morocco (Mousa Zadeh, et al, 2011, pp. $434 \& 642$, Opinions No. 2811, February $7^{\text {th }}, 1985$ and No. 78/21/6317 February $\left.28^{\text {th }}, 2000\right)$.

A recent outstanding example of a provisional application of a treaty in Iran is the application of the Protocol Additional to Safeguards Agreements approved in 1997, concerning the extensive supervision of the International Atomic Energy Agency (IAEA). As a result of international pressure, in the Paris Agreement of 2004, Iran promised to execute this protocol before its ratification by the Parliament (Note 10). This is legally known as a breach of the Constitution. Nevertheless, political considerations in that specific period, necessitated that the Parliament and the Guardian Council not make an objection to the issue. The Parliament did not ratify this protocol and Iran stopped the implementation of the protocol in 2005.

\section{Interpretation of the International Treaties}

The interpretation of the international treaties takes place at two levels, national and international. In some multilateral treaties, the competent authority for the interpretation is determined. In a number of treaties, the International Court of Justice (ICJ), the judicial body of the UN, has been considered as a competent authority, for the interpretation of treaties.

The national authorities can also perform the interpretation. The Constitution of Iran is silent on the interpretation of treaties; however, Article 73 declares that: "The interpretation of ordinary laws falls within the competence of the Islamic Consultative Assembly...”. It can be argued that the interpretation is to be made by the Parliament, since treaties have been considered as laws. Of course, a judge may have his/her own judicial interpretation as well, when a treaty is concerned. Based on the interpretative opinions of the Guardian Council, the interpretation of the ordinary law, by the Parliament, falls under Article 94 of the Constitution and it should 
be forwarded to the Guardian Council for approval (Guardian Council's Research Center, 2010, pp. 88-89, Opinion No. 9404, July $\left.27^{\text {th }}, 1983\right)$.

Meanwhile, under the principles of international law, a state is not allowed to justify its conduct, based on internal interpretation, if it is in conflict with the official international interpretation. For instance, in the case of the Oil Platforms (Iran v. USA), the United States justified its military attack for destroying the Iranian oil platforms (1987-88), under the provision of Article XX, paragraph 1 (d), of the 1955 Treaty of Amity, Economic Relations and Consular Rights between the United States of America and Iran. But, the International Court of Justice rejected the explanation made by the United States and held that the US was not entitled to rely on the provision of this Article (International Court of Justice Website: http://www.icj-cij.org/en/case/90).

\section{Ranking Status of the Treaties in Iran's Legal System}

States vary in terms of the approaches they have taken concerning the hierarchical ranking of international treaties in their internal legal order. Some countries, like Germany and France have regarded international treaties, superior to their ordinary laws (Constitution of France, Article 55 \& Constitution of Germany, Article 25). In the United States, despite the fact that the US Constitution has considered international treaties prior to the national law (Part 2 of Article 6), the Supreme Court considers treaties equal with the legislations passed by the Congress (Ziaei Bigdeli, 2009, pp. 87-88).

Under Iranian law, Article 9 of the Civil Code appears to consider treaties equal with ordinary laws: "The regulations of the treaties which have been legally signed between Iran and other states are as laws." This approach has been endorsed by the majority of lawyers and the practical trend reveals the same thing. The Constitution has not determined the manner of solving possible conflicts between treaties and ordinary laws. The Guardian Council, in its interpretative opinion, announces that if there is a conflict between two ordinary laws, chronological priority will be the criterion for decision making (Mousa Zadeh, et al, 2011, p. 310), Interpretative Opinion, No. $75 / 21 / 0650$ July $\left.2^{\text {nd }}, 1996\right)$. As it was formerly emphasized, since treaties have been recognized as ordinary laws, this instruction by the Guardian Council will be the criterion for decision making in case of conflict between a treaty and an ordinary law.

Despite the above implication, there still remains an objective interpretation concerning Article 9 of the Civil Code. Accordingly, the status of international treaties can be considered to be higher than that of ordinary laws. It can be argued that in this article, the lawmaker did not intend to determine the rank of international treaties within the national legal order; rather, the main intention was to imply that treaties are effective and valid like ordinary laws. In support of this claim, it is necessary to mention that Article 9 has been included under the title of "Publication, Effects and Application of Laws in General" in the Civil Code. Therefore, it can also be concluded that, in the case of conflict, international treaties logically should have priority over the ordinary laws, to avoid international responsibility.

\section{Conclusion}

In a brief review, it is true that the procedure of ratification and publication of international treaties in Iran is the same as that of internal ordinary laws. The treaties are published and come into force after they are passed by the Parliament, approved by the Guardian Council and signed by the President. The most outstanding characteristic of the Constitution of Iran is that it is based on Islamic rules. According to the Constitution, all of the legislations passed by the Parliament, including international treaties, should be compatible with religious regulations and the Constitution; the Guardian Council is the institution to take care of this issue. The council is an inseparable part of the legislative power; the Acts passed by the Parliament are not valid without its approval. Under the Constitution of Iran, the supremacy of the Guardian Council over the legislations passed by the Parliament is evident. Hence, all the legislations passed by the Parliament, including laws, treaties and even interpretive opinions of the Parliament, should be approved by the Guardian Council. Obviously, in the case of disapproval, the Parliament may insist on its passage and decide to send it to the 'Expediency Council'. In this case, the Expediency Council can approve the legislations passed by the Parliament despite the Guardian Council's disapproval. The last stage, that is the President's signing the treaties, is formal and if he evades it, the legislations passed by the Parliament will be published and come into force upon the order of the head of the Parliament. No distinction has been made in the Constitution between an official treaty and an executive agreement; however, based on the interpretive opinion of the Guardian Council, some treaties do not require ratification and they come into force through the signature of the executive authorities. Practically, an inclusive interpretation has been made of the opinions of the Guardian Council, so that a higher number of non-official treaties may come into force through signing. Nonetheless, the application of official treaties without going through the above-mentioned procedure of ratification, is a violation of the Constitution of Iran. Based on the 
explicit statement of Article 9 of the Civil Code of Iran, the widespread implication is that treaties are equal to the ordinary laws. Meanwhile, in order to avoid international responsibility, resulting from the violation of international treaties, Article 9 can be interpreted in a way that treaties are considered superior to the ordinary laws.

\section{References}

Act of Determining the Legal Deadline for Implementation of Article 123 of the Constitution, 1981.

Civil Code of the Islamic Republic of Iran, 1928.

Constitution of the Islamic Republic of Iran, 1979.

Enayat, S. H. (1991). Concluding International Treaties in the Contemporary Law of Iran, and Comparative Studies with the Islamic Jurisprudence and International Law. Tehran: Daftar-e Khadamat-e Hoghighi Beinolmalal.

Falsafi, H. (2000). International Law of Treaties. Tehran: Farhang-e Nashr-e Now.

Guardian Council's Research Center. (2010). Collection of Guardian Council Views: Interpretation and Advisory Regarding Constitution Articles, with Questions and Notifications (1st ed.). Tehran: Edareh-ye Chaap va Enteshar.

Haddadi, M. (2002). The Place of Executive Agreements in the Law of Iran. Journal of Higher Educational Complex of Qom, 4(14), 113-149.

Imani, A., \& Qetmiri, A. R. (2009). Constitution in the Legal System of Iran: History, Instructions and Laws. Tehran: Name-ye Hasti.

Internal Regulation of the Parliament, 1990.

Mehrpour, H. (2009). Summary of the Constitutional Law of the Islamic Republic of Iran. Tehran: Dadgostar Publication.

Regulation of the Manner of Making International Agreements, 1992.

Zadeh, M. et al. (Supervised by Elham, Gholamhossein). (2011). Constitutional Justice in the Islamic Republic of Iran: Articles of Constitution in the Light of Guardian Council's Opinions. Tehran: Edareh-ye Chaap va Enteshar.

Ziaei Bigdeli, M. R. (2009). Public International Law (38th, ed.). Tehran: Ganj-e Danesh Publications.

Websites:

Expediency Council Website (viewed on 3 July, 2017):

http://maslahat.ir/DocLib2/Approved\%20Policies/Noncompatabilities.aspx

International Court of Justice Website (viewed on 3 July, 2017):

http://www.icj-cij.org/en/case/90

UN Website, Treaty Collections, Glossary of terms: (viewed on 3 July, 2017):

https://treaties.un.org/Pages/Overview.aspx?path=overview/glossary/page1_en.xml

\section{Notes}

Note 1. The first constitution in the history of Iran, including 51 articles, was approved and announced by Mozaffar al-Din Shah Qajar, during the Constitutional Revolution, in December $30^{\text {th }}, 1906$.

Note 2. Also for more details about the process of passage of a treaty by the Parliament, see pp. 98-137.

Note 3. This regulation (approved by the Board of Ministers, May 3rd, 1992) clarifies the formation of executive and simple agreements.

Note 4. For further research on simple agreements in the law of Iran, see: Enayat, 1991, pp. 77-98.

Note 5. The Guardian Council rejected the passed legislation of the Islamic Consultative Assembly based on the articles 2, 3, 4, 10, 20, 21, 115, and 153 (Opinion No. 82/30/3972 dated August 18 ${ }^{\text {th }}, 2003$ ).

Note 6. This article also provides that "The permanent and changeable members of the Council shall be appointed by the Leader. The rules for the Council shall be formulated and approved by the Council members subject to the confirmation by the Leader." 
Note 7. For further study about the Expediency Council, see: Mehrpour, 2009, pp. 249-276.

Note 8. Passed on October 26th, 1991.

Note 9. Passed on November 20th, 1969.

Note 10. Paris Agreement between Iran and the three European states, namely, France, England, and Germany, signed in November $14^{\text {th }}, 2004$.

\section{Copyrights}

Copyright for this article is retained by the author(s), with first publication rights granted to the journal.

This is an open-access article distributed under the terms and conditions of the Creative Commons Attribution license (http://creativecommons.org/licenses/by/4.0/). 